\title{
Catalytic Enantioselective $\gamma$-Alkylation of Carbonyl Compounds
}

\section{Key words}

Suzuki crosscoupling

nickel

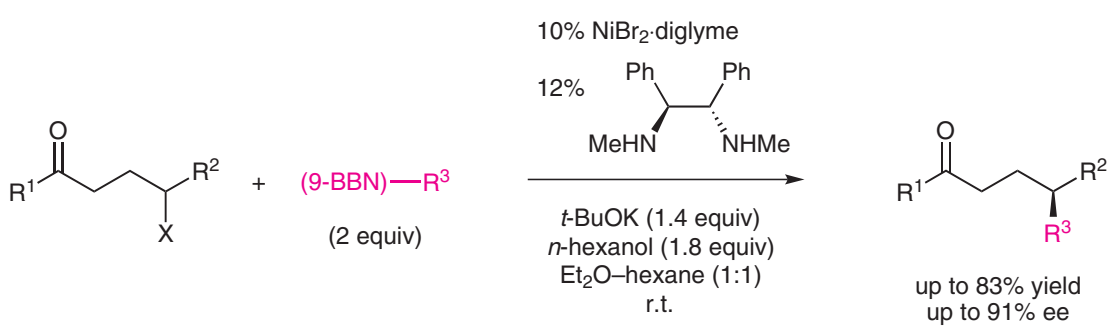

$\mathrm{R}^{1}=\mathrm{NPh}_{2}, \mathrm{~N}(\mathrm{OMe}) \mathrm{Me}$

$\mathrm{R}^{2}=\mathrm{Me}, \mathrm{Et}, n-\mathrm{Bu}, \mathrm{Bn}, j-\mathrm{Bu}$

$\mathrm{R}^{3}=$ various substituted alkyl groups

$\mathrm{X}=\mathrm{Cl}, \mathrm{Br}$

$\mathrm{BBN}=$ 9-borabicyclo[3.3.1]nonane

Selected examples:<smiles>CC(CCCCC1(C)OCCO1)CCC(N)=O</smiles>

$63 \%$ yield $85 \%$ ee<smiles>CCC(CCCC(=O)Nc1ccccc1)CCc1ccc(OC)cc1</smiles>

$80 \%$ yield $89 \%$ ee<smiles>CCCCC(CCCc1ccc(F)cc1)CCC(=O)Nc1ccccc1</smiles>

$64 \%$ yield<smiles>CCC(CCCc1ccccc1)CCC(=O)N(C)OC</smiles>

$75 \%$ yield (with $25 \% \mathrm{KI}$ ) $86 \%$ ee<smiles>CCC(CCCCO[Sb])CCC(=O)Nc1ccccc1</smiles>

$74 \%$ yield $91 \%$ ee
Significance: The authors describe a new method for the catalytic enantioselective $\gamma$ - (and $\delta$-)alkylation of carbonyl compounds by cross-coupling of $\gamma$ - (and $\delta$-)haloamides with alkylboranes. The reaction is catalyzed by nickel and uses a commercially available chiral diamine ligand to achieve high enantiomeric excess.
Comment: The reaction conditions tolerate alkyl chlorides as well as alkyl bromides as suitable electrophilic cross-coupling partners. Also, an aryl metal, a boronate ester, and a secondary alkyl metal compound are able to undergo the stereoselective cross-coupling with good enantiomeric excess. 